\title{
Article \\ Study on Annealing Process of Aluminum Oxide Passivation Layer for PERC Solar Cells
}

\author{
Yu-Chun Huang and Ricky Wenkuei Chuang * \\ Institute of Microelectronics, Department of Electrical Engineering, National Cheng Kung University, \\ 1 University Road, Tainan 70101, Taiwan; gn7101067001@gmail.com \\ * Correspondence: rwchuang@ee.ncku.edu.tw
}

Citation: Huang, Y.-C.; Chuang, R.W. Study on Annealing Process of Aluminum Oxide Passivation Layer for PERC Solar Cells. Coatings 2021, 11, 1052. https://doi.org/10.3390/ coatings11091052

Academic Editor: Alessio Lamperti

Received: 4 August 2021

Accepted: 25 August 2021

Published: 31 August 2021

Publisher's Note: MDPI stays neutral with regard to jurisdictional claims in published maps and institutional affiliations.

Copyright: (c) 2021 by the authors. Licensee MDPI, Basel, Switzerland. This article is an open access article distributed under the terms and conditions of the Creative Commons Attribution (CC BY) license (https:// creativecommons.org/licenses/by/ $4.0 /)$.

\begin{abstract}
In this study, Atomic Layer Deposition (ALD) equipment was used to deposit $\mathrm{Al}_{2} \mathrm{O}_{3}$ film on a p-type silicon wafer, trimethylaluminum (TMA) and $\mathrm{H}_{2} \mathrm{O}$ were used as precursor materials, and then the post-annealing process was conducted under atmospheric pressure. The $\mathrm{Al}_{2} \mathrm{O}_{3}$ films annealed at different temperatures between $200-500{ }^{\circ} \mathrm{C}$ were compared to ascertain the effect of passivation films and to confirm the changes in film structure and thickness before and after annealing through TEM images. Furthermore, the negative fixed charge and interface defect density were analyzed using the $\mathrm{C}-\mathrm{V}$ measurement method. Photo-induced carrier generation was used to measure the effective minority carrier lifetime, the implied open-circuit voltage, and the effective surface recombination velocity of the film. The carrier lifetime was found to be the longest $(2181.7 \mu \mathrm{s})$ for $\mathrm{Al}_{2} \mathrm{O}_{3} / \mathrm{Si}$ post-annealed at $400{ }^{\circ} \mathrm{C}$. Finally, with the use of VHF ( $40.68 \mathrm{MHz}$ ) plasma-enhanced chemical vapor deposition (PECVD) equipment, a silicon nitride $\left(\mathrm{SiN}_{\mathrm{x}}\right)$ film was plated as an antireflection layer over the front side of the wafer and as a capping layer on the back to realize a passivated emitter and rear contact (PERC) solar cell with optimal efficiency up to $21.54 \%$.
\end{abstract}

Keywords: $\mathrm{Al}_{2} \mathrm{O}_{3}$ film; ALD; PERC solar cell

\section{Introduction}

In recent years, passivated emitter and rear contact (PERC) solar cells have become a mainstream technology with improved efficiency. The most significant feature of PERC solar cells is the back passivation structure, which greatly reduces the dangling bond and surface recombination problems on the back of the silicon wafer [1].

The International Technology Roadmap for Photovoltaic (ITRPV) report shows that the efficiency of PERC solar cells continues to rise, and is expected to reach $23.5 \%$ by 2028, indicating the market share of PERC cells will continue to grow positively. It is also discussed that the market share of the process using ALD equipment to deposit AlOx films as the capping layer will exceed $10 \%$ in the future. The main reason is that $\mathrm{Al}_{2} \mathrm{O}_{3}$ films can effectively reduce the recombination current factor in the solar cells [2]. Therefore, reducing this surface recombination by surface passivation is very important for improving the performance of both solar cells with high stability for extreme applications [3] and low-cost and high-efficiency c-Si solar cells [4].

Recently it was proved that the negative fixed oxide charge in $\mathrm{Al}_{2} \mathrm{O}_{3}$ is beneficial to achieve good field-induced surface passivation of p-type silicon in solar cell applications [5-8]. This led to some research attention focusing on the electrical properties of $\mathrm{Al}_{2} \mathrm{O}_{3} / \mathrm{Si}$ systems [9-15] and it was pointed out that both chemical passivation and field-effect passivation play a role in improving the surface recombination properties [9-17]. $\mathrm{Al}_{2} \mathrm{O}_{3}$ films can be deposited by different techniques, such as sputtering $[18,19]$, plasma-enhanced chemical vapor deposition (PECVD) [11,12,15], and atomic layer deposition (ALD) [11,12,17,19].

In the ALD process, two different chemical precursors are usually introduced into the reaction chamber at different times to form two half-cycle reactions while all chemical reactions are restricted by surface chemisorptions on the surface. These two half-cycle 
reactions constitute an ALD cycle so that a monolayer film can be deposited. The two half-cycle reactions can be repeated under the conditions of self-limiting reaction, which is the ALD process window, to grow the film layer-by-layer. Two half-cycle reactions are used to deposit the film to avoid the simultaneous presence of two chemical precursors. Inside the reaction chamber, ALD technology can control the film thickness and uniformity with high precision [19-21].

So far, there have been many reports on how to optimize the deposition of $\mathrm{Al}_{2} \mathrm{O}_{3}$ thin films, such as using trimethylaluminum (TMA, $\mathrm{Al}_{2}\left(\mathrm{CH}_{3}\right)_{6}$ ) and $\mathrm{O}_{3}$ to deposit $\mathrm{Al}_{2} \mathrm{O}_{3}$ thin films [22,23]. Dueñas et al. reported the electrical properties of $\mathrm{Al}_{2} \mathrm{O}_{3}$-metal-insulator semiconductor structures prepared by ALD using $\mathrm{AlCl}_{3}$ and $\mathrm{H}_{2} \mathrm{O}$ [24]. The most commonly used precursors of ALD are TMA and $\mathrm{H}_{2} \mathrm{O}$ because they are volatile liquids that are easy to control during the manufacturing process and are inexpensive for cost-reduction in mass production [25].

Studies have found that most of the ALD processes using $\mathrm{H}_{2} \mathrm{O}$ grow a layer of $\mathrm{SiO}_{x}$ on the $\mathrm{Al}_{2} \mathrm{O}_{3} / \mathrm{Si}$ interface, and this interface layer is usually produced after the annealing process [26]. This interface layer plays a very important role in the chemical passivation of $\mathrm{Al}_{2} \mathrm{O}_{3} / \mathrm{Si}$. Therefore, post-annealing is a significant step for $\mathrm{Al}_{2} \mathrm{O}_{3}$. The energy provided by annealing can reorganize the structure of the $\mathrm{Al}_{2} \mathrm{O}_{3} / \mathrm{Si}$ interface, thereby increasing the negative fixed oxide charge and reducing the interface trap density [27]. The remarkable characteristics of $\mathrm{Al}_{2} \mathrm{O}_{3}$ are caused by the field-effect passivation due to the negative fixed charge formation at the interface $[26,28]$.

In this study, the $\mathrm{Al}_{2} \mathrm{O}_{3}$ films were deposited through the self-developed ALD equipment, using trimethylaluminum (TMA, $\left.\mathrm{Al}_{2}\left(\mathrm{CH}_{3}\right)_{6}\right)$ and water vapor $\left(\mathrm{H}_{2} \mathrm{O}\right)$ as precursors. The deposition wafer size of the PEALD equipment developed by our team was scaled up to $400 \mathrm{~mm} \times 400 \mathrm{~mm}$ to meet the R\&D and commercial demands. With the self-limiting reaction characteristics of ALD, which has an excellent uniform coverage, its film nonuniformity can reach $\leq \pm 3.88 \%$, while the nonuniformity at the middle of the $200 \mathrm{~mm} \times$ $200 \mathrm{~mm}$ substrate can be brought down to $\leq \pm 3 \%$.

The scale of our pilot production equipment with high uniformity and large area thin film deposition would undoubtedly improve the cost performance of solar cells. The selfmade equipment is highly autonomous while the distance between the substrate and the showerhead can be comfortably adjusted. The foregoing merits unequivocally demonstrate our self-made equipment is poised to be an indispensable tool for delivering high-quality works for research and development, including the PERC solar cells investigated in the present study.

The $\mathrm{Al}_{2} \mathrm{O}_{3}$ films thus prepared were then subjected to a post-annealing process in the atmosphere, and the temperature is controlled between $200-500{ }^{\circ} \mathrm{C}$. A systematic study of the effects of temperature on silicon wafer performance in the atmosphere (ATM) was then conducted. The comparison of the electrical properties and structural characteristics of the $\mathrm{Al}_{2} \mathrm{O}_{3} / \mathrm{Si}$ interface caused by the adjustment of the annealing process temperature are also discussed. Finally, quasi-steady-state photo-conduction (QSSPC) and solar cell efficiency were compared to verify the characteristics of PERC solar cells under different annealing parameters.

\section{Materials and Methods}

\subsection{Thin Film Deposition Process}

The substrate adopted in this study was a p-type (boron-doped) $\mathrm{Si}(100)$ grown by the Czochralski (CZ) method, with a resistance of $1 \Omega-\mathrm{cm}$ and a thickness of $200 \mu \mathrm{m}$. Then we used the RCA (Radio Corporation of America, New York, NY, USA) cleaning standard cleaning process to clean the surface of the silicon wafer. Before the deposition process, a hydrofluoric acid infiltration was required to remove the native oxide layer on the surface of the wafer. 
Figures 1 and 2 show the schematic diagrams of the film structure for the experimental samples and the coating process. The passivation $\mathrm{Al}_{2} \mathrm{O}_{3}$ film is deposited on the back of the wafer using the atomic layer deposition system (ALD) equipment. This ALD equipment was developed and manufactured by our research group as illustrated in Figure 3 . The silicon nitride $\left(\mathrm{SiN}_{\mathrm{x}}\right)$ film located on the front side of the wafer behaves as the anti-reflection layer while the $\mathrm{SiN}_{\mathrm{X}}$ film on the back acts as the capping layer, all of which are deposited using the VHF (40.68 MHz) plasma-enhanced chemical vapor deposition (PECVD) system. This VHF PECVD equipment was also developed and manufactured by our research group. The advantage of the VHF plasma source is that it can simultaneously increase the electron density and reduce the ion bombardment energy; the former can increase the coating rate while the latter can avoid film damage and ensure film quality [29].

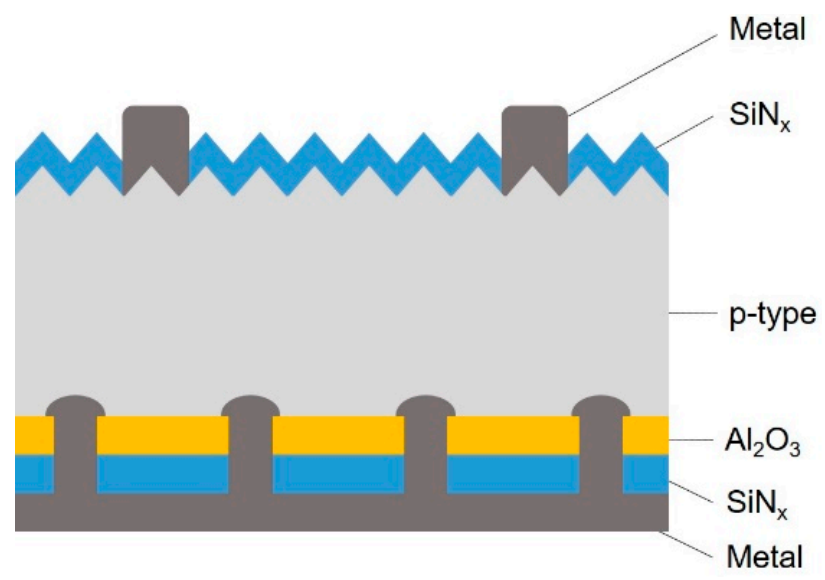

Figure 1. Structure of the thin-film PERC solar cell.

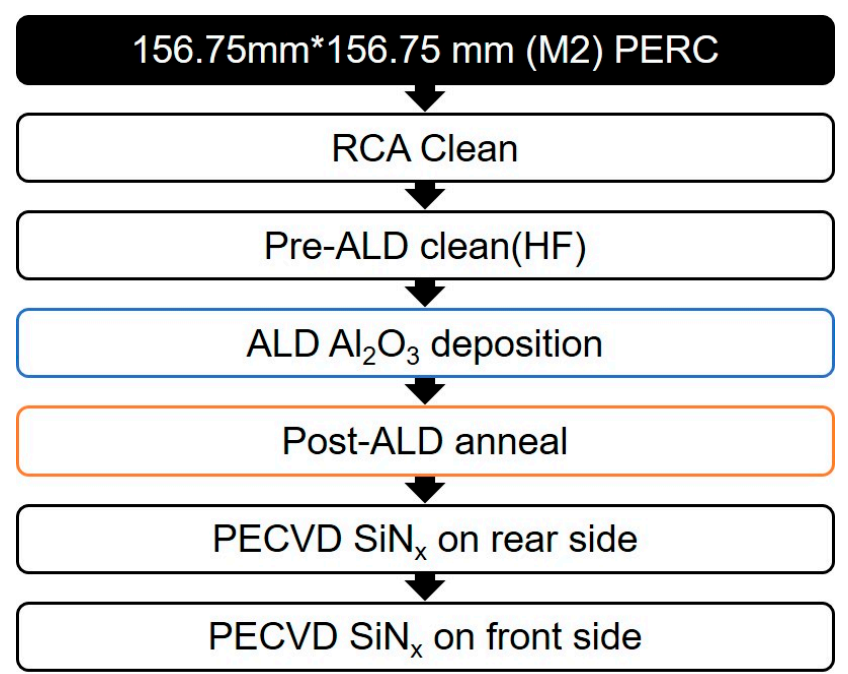

Figure 2. Deposition process flow chart. 


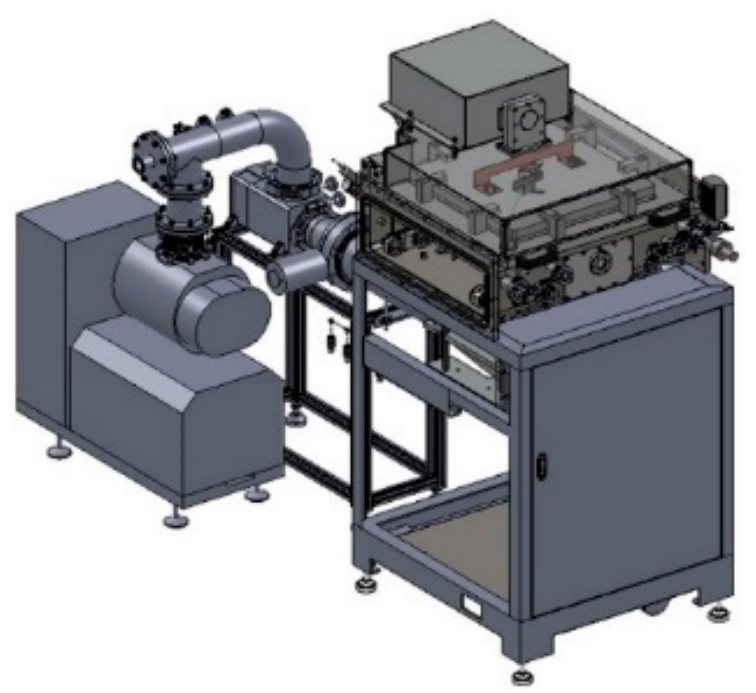

Figure 3. Schematic diagram of ALD equipment.

The measurement of the effective minority carrier lifetime is made with a doublesided $\mathrm{Al}_{2} \mathrm{O}_{3}$ film structure. The $\mathrm{Al}_{2} \mathrm{O}_{3}$ film is deposited with trimethylaluminum (TMA, $\left.\mathrm{Al}_{2}\left(\mathrm{CH}_{3}\right)_{6}\right)$ with water vapor $\left(\mathrm{H}_{2} \mathrm{O}\right)$ used as precursors and the deposition is carried out for 24 cycles. The deposition thickness is about $4 \mathrm{~nm}$. The process parameters of $\mathrm{Al}_{2} \mathrm{O}_{3}$ thin films deposited by ALD equipment are shown in Table 1. In the choice of passivation film material, $\mathrm{Al}_{2} \mathrm{O}_{3}$ film was selected because of its high charge density, which can provide good passivation over the surface of p-type wafers, while it is also common to coat it on the back surface of PERC solar cells for mass production. There are two main mechanisms for the $\mathrm{Al}_{2} \mathrm{O}_{3}$ passivation, namely, the chemical passivation and field-effect passivation, both of which are relied upon to improve the effective minority carrier lifetime. The chemical passivation produced by $\mathrm{Al}_{2} \mathrm{O}_{3}$ films can reduce the dangling bonds on the wafer surface. The field-effect passivation produced by $\mathrm{Al}_{2} \mathrm{O}_{3}$ films is related to the $\mathrm{Q}_{\mathrm{f}}$ (the negative fixed charge) in the $\mathrm{Al}_{2} \mathrm{O}_{3}$ layer, while the negative fixed charge causes band bending.

Table 1. Deposition parameters of the $\mathrm{ALD}_{2} \mathrm{O}_{3}$ layer.

\begin{tabular}{cc}
\hline Parameters & Value \\
\hline Substrate temperature $\left({ }^{\circ} \mathrm{C}\right)$ & 150 \\
TMA bubbler temperature $\left({ }^{\circ} \mathrm{C}\right)$ & 17.5 \\
$\mathrm{H}_{2} \mathrm{O}$ bubbler temperature $\left({ }^{\circ} \mathrm{C}\right)$ & 45 \\
TMA flow rate $(\mathrm{sccm})$ & 200 \\
$\mathrm{H}_{2} \mathrm{O}$ flow rate $(\mathrm{sccm})$ & 500 \\
Thickness $(\mathrm{nm})$ & 4 \\
\hline
\end{tabular}

An $\mathrm{SiN}_{\mathrm{x}}$ film is deposited on the front side of the wafer as an anti-reflection layer and an $\mathrm{SiN}_{\mathrm{x}}$ film is coated on the back as a cover layer. The process parameters of $\mathrm{SiN}_{\mathrm{x}}$ film deposition using PECVD equipment are shown in Table 2. The gas flow ratio of $\mathrm{N}_{2}$ to $\mathrm{SiH}_{4}$ is 10 , the substrate temperature is $150{ }^{\circ} \mathrm{C}$, the RF power is $70 \mathrm{~mW} / \mathrm{cm}^{2}$, the pressure is $400 \mathrm{mTorr}$, and the deposition thickness is $30 \mathrm{~nm}$. Since the extinction coefficient of $\mathrm{SiN}_{\mathrm{x}}$ films is very low, even for high absorption typically occurring in the short wavelength range, it falls between $10^{-4}$ and $10^{-5}$. Hence, as a passivation film, it would not affect the absorption efficiency of silicon wafers [30]. 
Table 2. Deposition parameters of the PECVD SiN $\mathrm{X}_{\mathrm{x}}$ layer.

\begin{tabular}{cc}
\hline Parameters & Value \\
\hline Substrate temperature $\left({ }^{\circ} \mathrm{C}\right)$ & 150 \\
Pressure (mTorr) & 400 \\
$\mathrm{~N}_{2} / \mathrm{SiH}_{4}$ ratio & 10 \\
$\mathrm{RF}$ power $\left(\mathrm{mW} / \mathrm{cm}^{2}\right)$ & 70 \\
Thickness $(\mathrm{nm})$ & 30 \\
Electrode spacing $(\mathrm{mm})$ & 30 \\
\hline
\end{tabular}

\subsection{Annealing Process}

With the use of the high-temperature furnace for the post-annealing process, the passivation quality could be improved accordingly to achieve a high-performance PERC solar cell. Since high-temperature annealing can increase the negative fixed charge and reduce the interface defect density, the post-annealing process is operated by adjusting the process temperature, process time, and the type of forming gas. In this study, the passivation annealing process was performed by adjusting different process temperatures in the atmosphere (ATM) to explore the structural and electrical properties of the $\mathrm{Al}_{2} \mathrm{O}_{3} / \mathrm{c}-$ $\mathrm{Si}$ interface. For the $\mathrm{SiN}_{\mathrm{x}} / \mathrm{c}-\mathrm{Si} / \mathrm{Al}_{2} \mathrm{O}_{3} / \mathrm{SiN}_{\mathrm{x}}$ passivation structure undergoing annealing, the process temperature was adjusted between 200 and $500{ }^{\circ} \mathrm{C}$, the heating rate to $5^{\circ} \mathrm{C}$ per minute, and the annealing process maintained at the set temperature for $10 \mathrm{~min}$. The annealing temperature profile is shown in Figure 4.

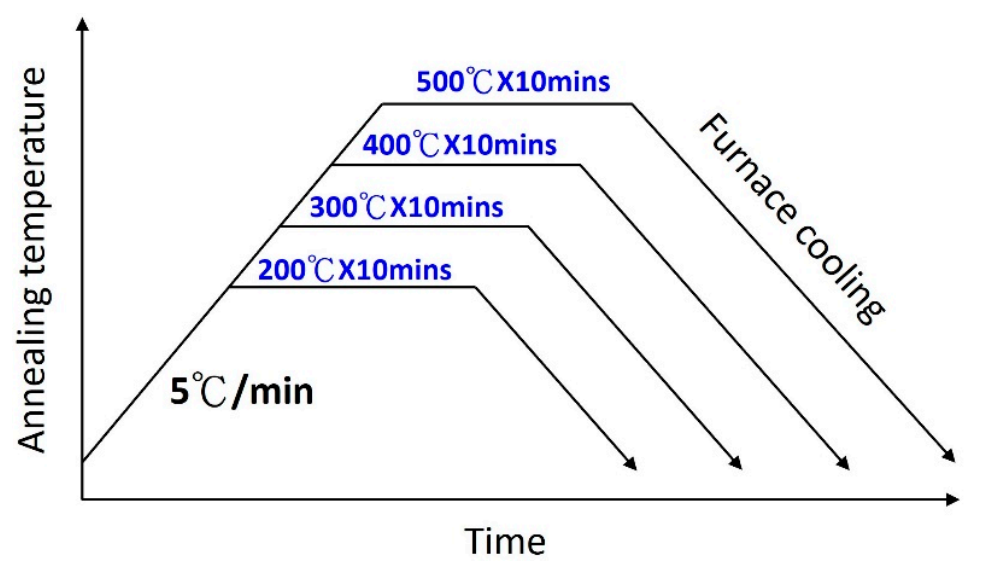

Figure 4. The heating curve of different annealing conditions.

A field emission gun transmission electron microscope (FEGTEM, Philips, Amsterdam, Netherlands) was used to observe the $\mathrm{Al}_{2} \mathrm{O}_{3} / \mathrm{Si}$ interface. At $200 \mathrm{kV}$, its point-to-point resolution in TEM mode is $0.23 \mathrm{~nm}$. The capacitance-voltage $(\mathrm{C}-\mathrm{V})$ measurement was performed via the Keithly 4200 system (Solon, OH, USA) on the sample incorporating a thermally-evaporated $\mathrm{Al}$ point electrode with a diameter of $100 \mu \mathrm{m}$ on the $\mathrm{Al}_{2} \mathrm{O}_{3}$ film. The $\mathrm{C}-\mathrm{V}$ experiment bias voltage range was set between -3 and $+3 \mathrm{~V}$ to obtain $50 \mathrm{mV}$ signal parameters at 1,100, and $1000 \mathrm{kHz}$. Therefore, due to the standard planar capacitor equation, the dielectric constant of alumina was calculated based on the accumulated capacitance value, and the accuracy of the entire technique estimated to be $\pm 5 \%$. We used WCT-120 equipment (Sinton Consulting Inc. Boulder, CO, USA) to determine the minority carrier lifetime and the accompanied open-circuit voltage of the wafer, using the quasi-steady-state photoconductance (QSSPC) method. The main principle is that the optical excitation flash produces carriers in the chip and electron-hole pairs are generated. The more carriers that are generated the better it is for the conductivity, knowing that the conductivity increase is proportional to the increase of carriers. The current density and voltage relationship (J-V) measurement was performed by a dual-light source solar simulator (Wacom Co., Kazo, 
Japan) using Xenon lamps and halogen lamps as the calibration for the AM 1.5G solar simulation spectrum.

\section{Results and Discussion}

\subsection{Microstructure}

A field emission gun transmission electron microscope (FEGTEM) was used to observe the $\mathrm{Al}_{2} \mathrm{O}_{3} / \mathrm{Si}$ interface. Figure 5 shows a transmission electron microscope (TEM) image of $\mathrm{Al}_{2} \mathrm{O}_{3}$ and $\mathrm{SiN}_{\mathrm{x}}$ deposited on a silicon substrate to confirm the state of the $\mathrm{Al}_{2} \mathrm{O}_{3} / \mathrm{c}-$ $\mathrm{Si}$ interface before annealing (Figure $5 \mathrm{a}$ ) and under different annealing temperatures (Figure $5 b-e$ ) for measuring the corresponding $\mathrm{SiO}_{2}$ film thicknesses. Based on Figure $5 \mathrm{a}$, the $\mathrm{SiN}_{\mathrm{x}}$ film deposited by PECVD is about $33 \mathrm{~nm}$, meanwhile, the $\mathrm{Al}_{2} \mathrm{O}_{3}$ film deposited by ALD is about $3.5 \mathrm{~nm}$. No $\mathrm{SiO}_{2}$ layer is formed without annealing. Figure $5 \mathrm{~b}$ shows annealing at $200{ }^{\circ} \mathrm{C}$ for $10 \mathrm{~min}$ when a very thin $\mathrm{SiO}_{2}$ layer is formed with a film thickness of about $0.7 \mathrm{~nm}$. Figure $5 \mathrm{c}$ shows annealing at $300{ }^{\circ} \mathrm{C}$ when a $\mathrm{SiO}_{2}$ layer thickness of about $1 \mathrm{~nm}$ is formed. Figure $5 \mathrm{~d}$ shows annealing at $400{ }^{\circ} \mathrm{C}$ when a $\mathrm{SiO}_{2}$ layer thickness of about $2 \mathrm{~nm}$ is formed. Finally, Figure 5e shows annealing at $500{ }^{\circ} \mathrm{C}$ when an $\mathrm{SiO}_{2}$ layer thickness of about $3.4 \mathrm{~nm}$ is formed. The thickness of the $\mathrm{SiO}_{2}$ layer increases as the annealing temperature increases. This phenomenon is due to the substrate surface oxidation caused by the post-annealing process to form $\mathrm{Si}-\mathrm{O}$ bonding [1] where the oxygen composition is provided from the atmosphere during the annealing process. The oxygen in the atmosphere penetrates the surface of the silicon substrate with the energy provided by the annealing to exchange with the $\mathrm{Al}_{2} \mathrm{O}_{3}$ film to develop a $\mathrm{SiO}_{2}$ layer.
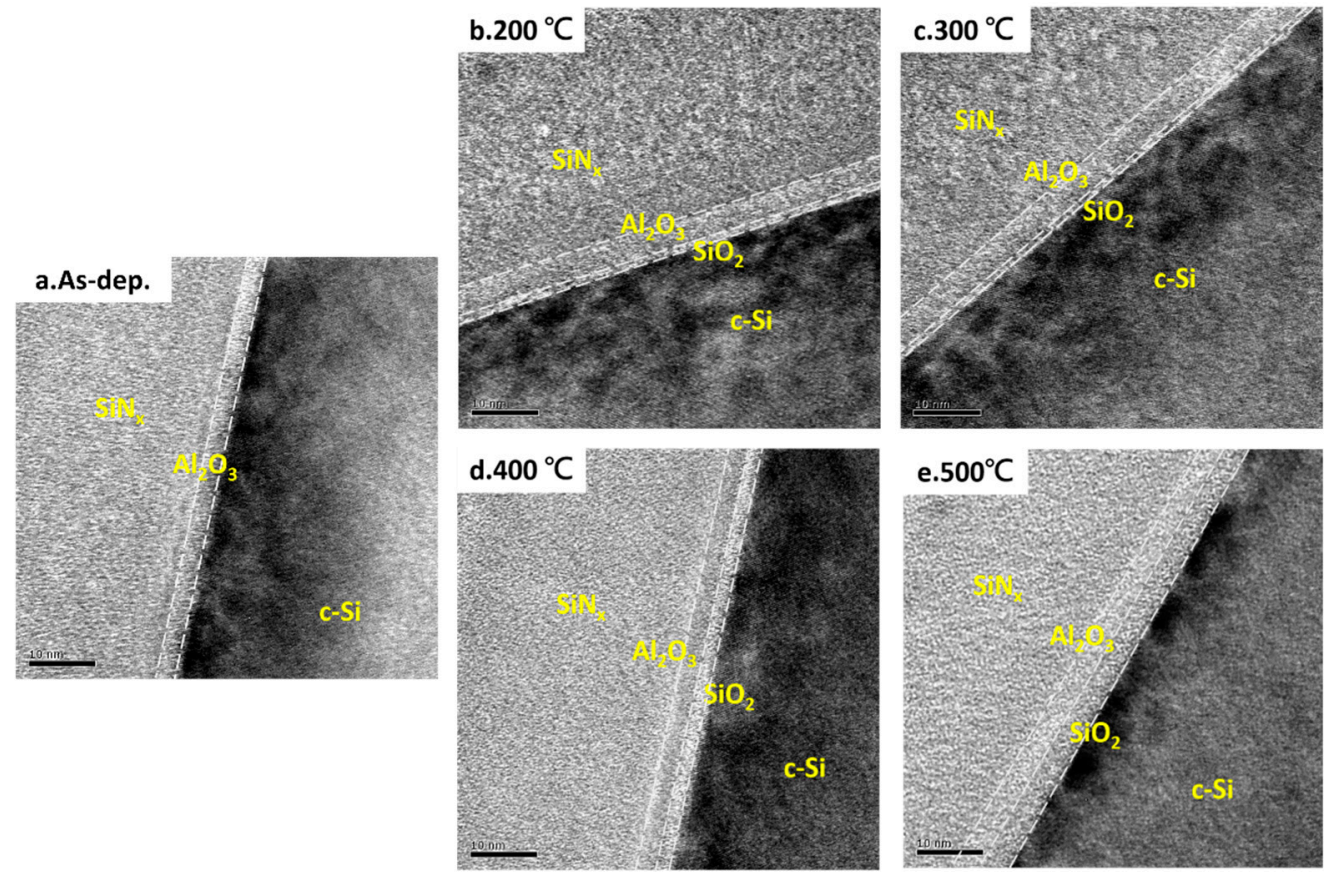

Figure 5. TEM images of the $\mathrm{Al}_{2} \mathrm{O}_{3} / \mathrm{Si}$ samples annealed in (a) as-deposited, (b) $200{ }^{\circ} \mathrm{C},(\mathbf{c}) 300{ }^{\circ} \mathrm{C}$, (d) $400{ }^{\circ} \mathrm{C}$, and (e) $500{ }^{\circ} \mathrm{C}$.

The result as shown in Figure 6 indicates that the thickness of the $\mathrm{SiO}_{2}$ layer increases as the annealing temperature increases. The relationship between the thickness of the $\mathrm{SiO}_{2}$ layer and the negative fixed charge and effective minority carrier lifetime are discussed later. 


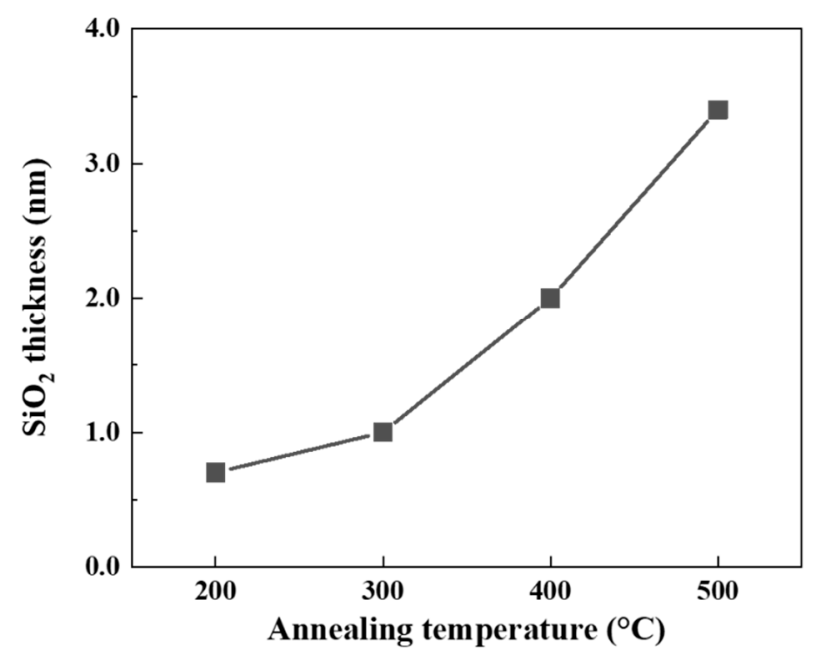

Figure 6. The thickness of the $\mathrm{SiO}_{2}$ layer at different annealing temperatures.

\subsection{C-V Measurement}

The capacitance-voltage $(\mathrm{C}-\mathrm{V})$ measurement was performed on $\mathrm{Al} / \mathrm{Al}_{2} \mathrm{O}_{3} / \mathrm{Si} \mathrm{MOS}$ samples annealed at $200-500{ }^{\circ} \mathrm{C}$ using a high-temperature furnace in the atmosphere (ATM). The negative fixed charge $\left(-Q_{f}\right)$ density at the sample interface corresponding to the different annealing temperatures is illustrated In Figure 7a. These values were measured by the $\mathrm{C}-\mathrm{V}$ technique and the density of the negative charge is calculated by Equation (4) [31]. The capacitance of the accumulated layer $C_{o x}$ is first determined to evaluate the relative permittivity $\varepsilon_{\text {oxide }}$ of the oxide layer according to Equation (1):

$$
C_{o x}=\frac{\left(\varepsilon_{0} \varepsilon_{o x i d e} A\right)}{t_{o x}}
$$

where $t_{o x}$ is the thickness of the oxide layer, $\varepsilon_{0}$ is the vacuum dielectric constant, and $A$ is the electrode area of the MOS structure. Then Equation (2) is used to calculate the $L_{D}$ (Debye length):

$$
L_{D}=\sqrt{\frac{\varepsilon_{s i} \varepsilon_{0} K T}{q^{2} N_{a}}}
$$

where $\varepsilon_{s i}$ is the relative permittivity of the silicon substrate, $K$ is the Boltzmann constant, $T$ is the absolute temperature, $q$ is the unit charge, and $N_{a}$ is the concentration of the silicon substrate, and then the flat band capacitance $C_{F B}\left(\mathrm{~F} / \mathrm{cm}^{2}\right)$ can be calculated using Equation (3):

$$
C_{F B}=\frac{1}{\frac{t_{o x}}{\varepsilon_{0} \varepsilon_{o x i d e}}+\frac{L_{D}}{\varepsilon_{0} \varepsilon_{s i}}}
$$

where $t_{o x}$ is the thickness of the oxide layer, $\varepsilon_{0}$ is the vacuum permittivity, $\varepsilon_{o x i d e}$ is the relative permittivity of the oxide layer, and $\varepsilon_{s i}$ is the relative permittivity of the silicon substrate. Thus, with the help of the C-V curve corresponding to the flat band voltage $V_{F B}$ and Equation (4), the fixed charge $Q_{f}\left(\mathrm{~cm}^{-2}\right)$ can be determined as:

$$
Q_{f}=\frac{\left(\varphi_{m s}-V_{F B}\right) C_{o x}}{q A}
$$

where $q$ is the unit charge, $A$ is the electrode area of the MOS structure, $\varphi_{m s}$ is the work function difference between the metal and the semiconductor, and $V_{F B}$ is the flat band voltage. 


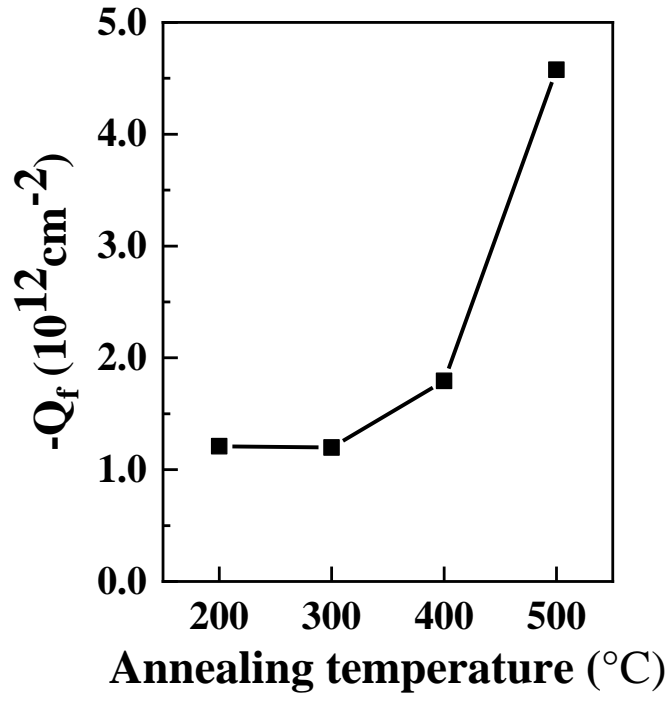

(a)

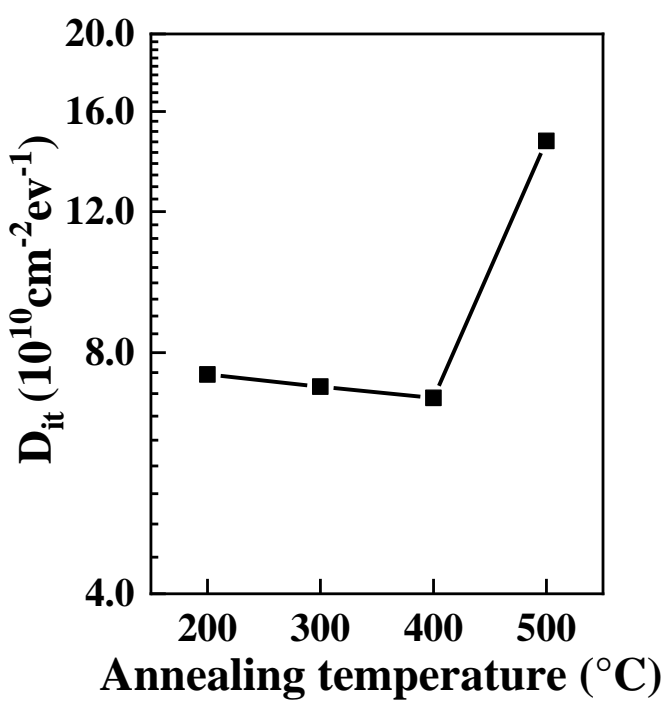

(b)

Figure 7. The $\mathrm{C}-\mathrm{V}$ measurement of $\mathrm{Al} / \mathrm{Al}_{2} \mathrm{O}_{3} / \mathrm{Si}$ MOS samples annealed at $200-500{ }^{\circ} \mathrm{C}$ in ATM. (a) negative fixed charge $\left(-Q_{f}\right)$, (b) defect density $\left(D_{i t}\right)$.

Figure $7 \mathrm{a}$ shows that as the annealing process temperature increases from 200 to $500{ }^{\circ} \mathrm{C}$ the negative $Q_{f}$ value increases. The measured $Q_{f}$ are $-1.21 \times 10^{12},-1.20 \times 10^{12}$, $-1.79 \times 10^{12}$, and $-4.58 \times 10^{12} \mathrm{~cm}^{-2}$ at annealing temperature of $200,300,400$, and $500{ }^{\circ} \mathrm{C}$ respectively. The result of high $Q_{f}$ reflects the high charge density of the $\mathrm{Al}_{2} \mathrm{O}_{3}$ films deposited by the ALD equipment, successfully developed by our research group. In this study, the negative charge of $\mathrm{Al}_{2} \mathrm{O}_{3}$ was attributed to the excess oxygen in the $\mathrm{Al}_{2} \mathrm{O}_{3}$ films. The maintenance of ambient atmosphere (ATM) for annealing provides more oxygen than the post-annealing using $\mathrm{N}_{2}$, while a higher annealing temperature results in a higher negative charge density at the interface. The increase in charge density can be attributed to the chemical composition of the $\mathrm{AlO}_{x}$ layer at the $\mathrm{c}-\mathrm{Si} / \mathrm{Al}_{2} \mathrm{O}_{3}$ interface. By comparing the thickness trend of the $\mathrm{SiO}_{2}$ layer in Figures 6 and 7a, it can be shown that the increase in the thickness of the oxide layer has a positive effect on the negative charge density.

The defect density, $D_{i t}$, is estimated from the same $\mathrm{C}-\mathrm{V}$ measurement and can be calculated using the following Equation (5) [31]:

$$
D_{i t}=\frac{2 \omega C_{o x}^{2} G_{\max }}{q A\left\{G_{\max }{ }^{2}+\omega^{2}\left[C_{o x}-C_{m}\left(G_{\max }\right)\right]^{2}\right\}}
$$

As shown in Figure $7 \mathrm{~b}$, the lowest value of $D_{i t}$ is $7.51 \times 10^{10} \mathrm{~cm}^{-2} \cdot \mathrm{eV}^{-1}$ at annealing temperature $400{ }^{\circ} \mathrm{C}$. The other $D_{i t}$ values are $7.25 \times 10^{10}, 7.02 \times 10^{10}$, and $1.47 \times 10^{10} \mathrm{~cm}^{-2} \cdot \mathrm{eV}^{-1}$ at annealing temperature at 200,300 , and $500{ }^{\circ} \mathrm{C}$ respectively. Lattice defects on the surface of the silicon wafer substrate are considered to be very detrimental, and these defects are expected to introduce carrier trapping to prevent the effectiveness of surface passivation. The analysis of $D_{i t}$ shows oxygen in the ATM interacting with the dangling bond in the silicon substrate which is responsible for the chemical passivation process. In addition to the control temperature that dictates the annealing process, the high quality of the ALD coating process is also a key control factor.

\subsection{QSSPC Method}

The effective minority carrier lifetime $\left(\tau_{\text {eff }}\right)$ of photo-generated carriers is an important parameter dictating the quality of ALD-deposited $\mathrm{Al}_{2} \mathrm{O}_{3}$ films as the passivation layer of the p-Si wafer. The WCT-120 Silicon Wafer Lifetime Tester (manufactured by Sinton 
Consulting Inc., Boulder, CO, USA) was used with the adoption of the quasi-steadystate photoconductance (QSSPC) method for the $\tau_{\text {eff }}$ measurement. Figure 8 shows the effective minority carrier lifetime $\left(\tau_{\text {eff }}\right)$ data for $\mathrm{Al}_{2} \mathrm{O}_{3} / \mathrm{Si}$ samples at different annealing temperatures. The annealing temperature was set between 200 and $500{ }^{\circ} \mathrm{C}$ to quantify and compare the $\tau_{\text {eff }}$ before and after annealing. Figure 9 shows the value of $\tau_{\text {eff }}$ obtained at the injection level of $5 \times 10^{15} \mathrm{~cm}^{-3}$. The results show that $\tau_{\text {eff }}$ is only $54.60 \mu$ s before annealing, while $\tau_{\text {eff }}$ reaches $2181.72 \mu$ s at $400{ }^{\circ} \mathrm{C}$, which is the best performance yet among all parameters. The measurements of other $\tau_{\text {eff }}$ are as follows: $392.90,906.30$, and $1450.30 \mu \mathrm{s}$ at annealing temperature 200,300 , and $500{ }^{\circ} \mathrm{C}$, respectively. The effective carrier lifetime $\left(\tau_{\text {eff }}\right)$ can be estimated by considering the carrier interactions that occur at the bulk and surface levels by following Equation (6) [4,26,32]:

$$
\frac{1}{\tau_{e f f}}=\frac{1}{\tau_{b u l k}}+\frac{2 S_{e f f}}{W}
$$

where $\tau_{\text {bulk }}$ is the lifetime within the bulk sample. The value of the p-Si wafer used was more than $4 \mathrm{~ms}$ (data provided by the wafer supplier), $W$ refers to the thickness of the wafer $(200 \mu \mathrm{m})$, and $S_{\text {eff }}$ is the effective surface recombination velocity (SRV). It can be assumed that the two sides are equal for a symmetrical structure. Since the substrate used in this experiment was a high-quality silicon wafer with a very long $\tau_{b u l k}$, it is reasonable to expect $\tau_{\text {eff }}$ to be mainly affected by surface recombination. Under this approximation, we can simplify Equation (6) as

$$
S_{e f f} \leq \frac{W}{2 \tau_{e f f}}
$$

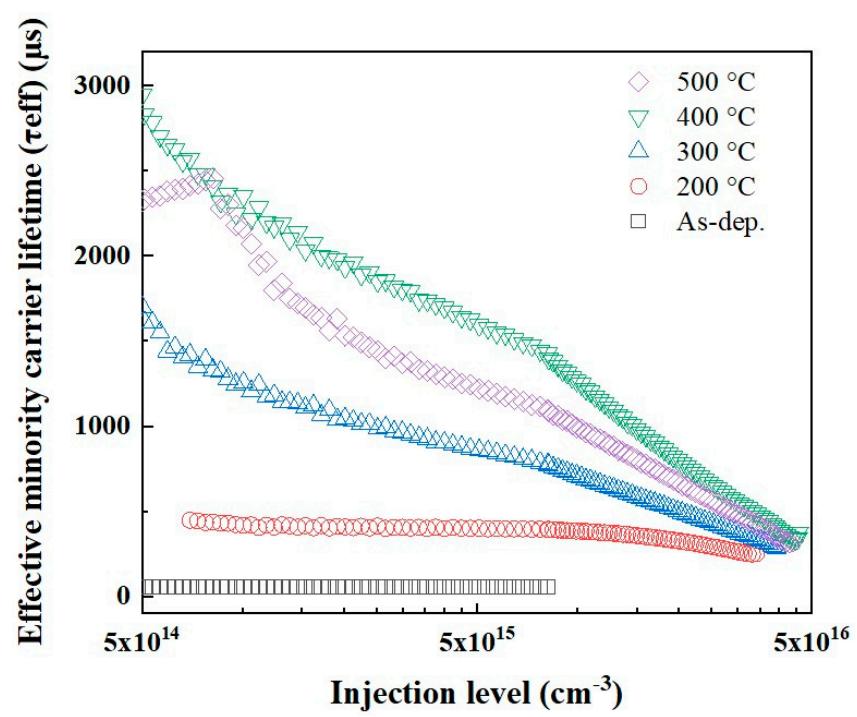

Figure 8. The effective minority carrier lifetime of $\mathrm{Al}_{2} \mathrm{O}_{3} / \mathrm{Si}$ samples at different annealing temperatures (with various levels of injection). 


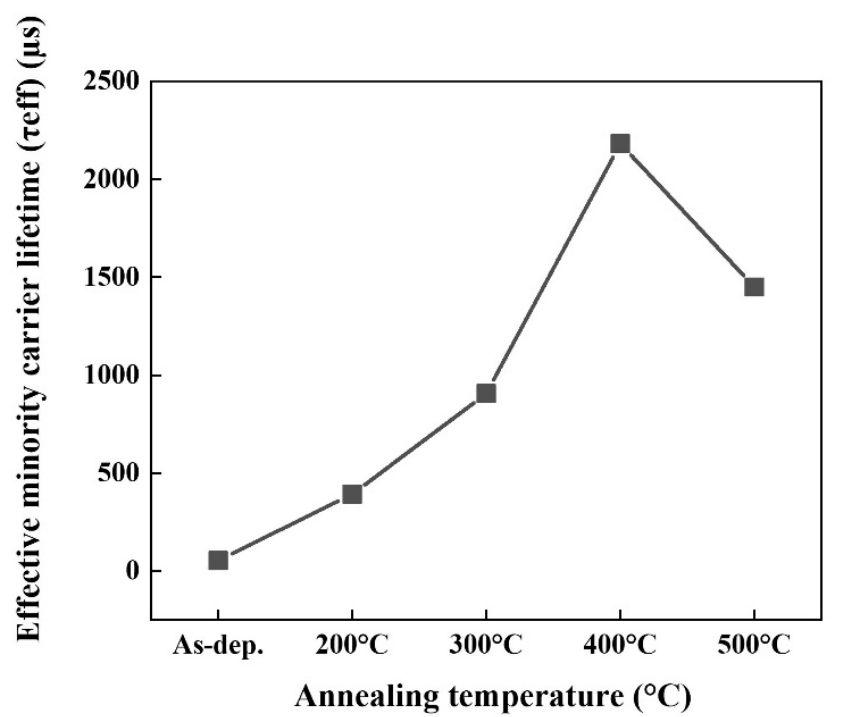

Figure 9. The effective minority carrier lifetime of $\mathrm{Al}_{2} \mathrm{O}_{3} / \mathrm{Si}$ samples at different annealing temperatures (at the injection level of $5 \times 10^{15} \mathrm{~cm}^{-3}$ ).

Figure 10 depicts the maximum effective surface recombination velocity (SRV) $S_{\text {eff }}$ values calculated before annealing and also at the different annealing temperatures. It can be seen from the graph that the surface recombination rate before annealing is about $183.15 \mathrm{~cm} / \mathrm{s}$, and then drops down to the lowest recombination rate of $4.58 \mathrm{~cm} / \mathrm{s}$ at $400{ }^{\circ} \mathrm{C}$. The other values of $S_{\text {eff }}$ are $25.45,11.03$, and $6.90 \mathrm{~cm} / \mathrm{s}$ for annealing at 200,300 , and $500{ }^{\circ} \mathrm{C}$, respectively. From a component point of view, the lower the SRV, the better the passivation effect of the surface and the less the number of carriers lost during the recombination process. Therefore, to minimize the surface recombination phenomenon, the appropriate chemical passivation is necessary. On the other hand, to sizably reduce the interface defects, the extremely low $\mathrm{SRV}$ achieved at $400{ }^{\circ} \mathrm{C}$ using ATM in this study signifies that the $\mathrm{Al}_{2} \mathrm{O}_{3}$ passivation film deposited by ALD has effectively reduced the dangling bonds on the surface of the silicon substrate.

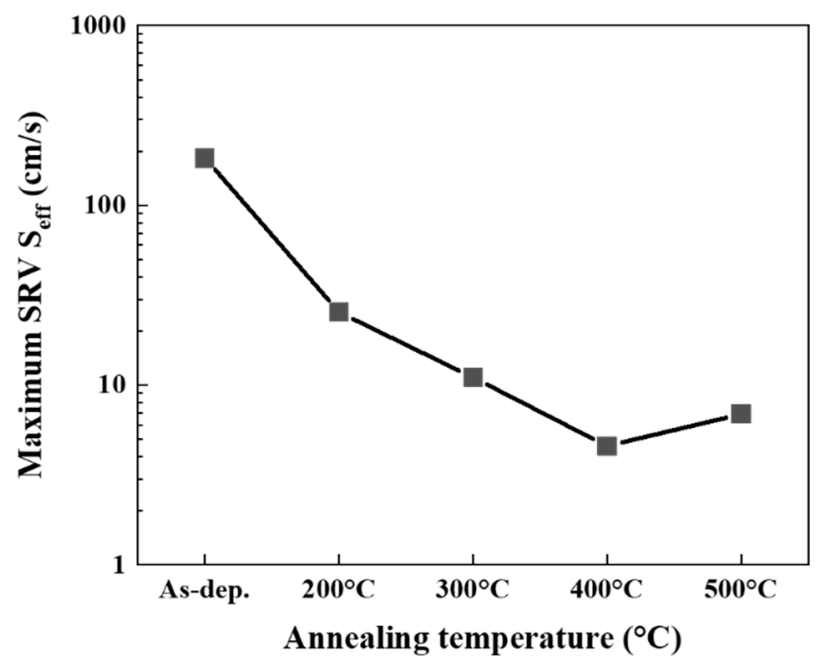

Figure 10. The maximum effective surface recombination velocity (SRV) of $\mathrm{Al}_{2} \mathrm{O}_{3} / \mathrm{Si}$ samples before annealing and at the different annealing temperatures.

The implied open-circuit voltage $\left(V_{o c}\right)$ measurement is used here as another parameter to qualify different dielectrics and deposition techniques when passivating the silicon 
surface [30]. It is calculated from the $\tau_{\text {eff }}(\Delta n)$ measured by QSSPC, and the calculation Equation (8) is as follows [33]:

$$
I V_{o c}=\frac{K T}{q} \ln \left(\frac{\Delta n(p+\Delta n)}{n_{i, e f f^{2}}}\right)
$$

where $\Delta n$ is the minority carrier concentration measured by WCT-120 under one solar condition, $\mathrm{p}$ is the hole concentration, and $n_{i, \text { eff }}$ is the intrinsic concentration.

Since this measurement is performed before the screen-printed electrode, this value is assumed to reflect the maximum $V_{o c}$ that can be achieved based on the internal material quality without the contributions of optical loss or imperfect contact loss.

From Figure 11, it can be observed that the $I V_{o c}$ value has the same trend as the $\tau_{\text {eff }}$ depicted in Figure 10. The best $I V_{o c}$ value is $727 \mathrm{mV}$ at $400{ }^{\circ} \mathrm{C}$. $I V_{o c}$ values are 680 , 707 , and $718 \mathrm{mV}$, which correspond to the annealing temperature set at 200, 300, and $500{ }^{\circ} \mathrm{C}$, respectively. Compared with $627 \mathrm{mV}$ realized before annealing, the importance of annealing can be highlighted as an essential and critical step for a high-efficiency solar cell process.

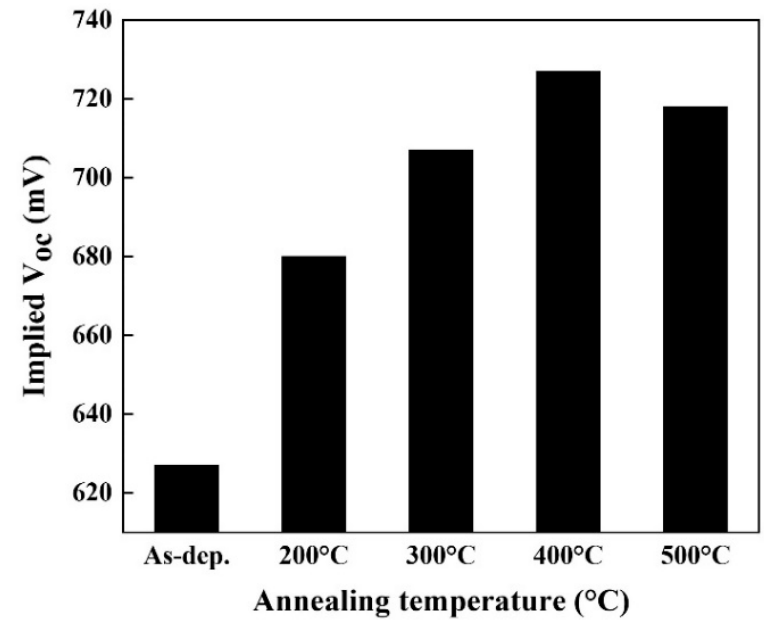

Figure 11. The implied open-circuit voltage $\left(I V_{o c}\right)$ of $\mathrm{Al}_{2} \mathrm{O}_{3} / \mathrm{Si}$ samples before annealing and the different annealing temperatures.

In this study, the $\mathrm{Al}_{2} \mathrm{O}_{3}$ films deposited by ALD were used as the passivation layer of the PERC solar cell. As illustrated in Figure 12, two major factors dominate the passivation mechanisms: chemical passivation and field-effect passivation. The chemical passivation effect is to reduce the generation of dangling bonds on the wafer surface and is responsible for $D_{i t}$ and SRV from the above analysis and discussion. On the other hand, the field-effect passivation is dominated by the characteristics of $Q_{f}$. The effective minority carrier lifetime $\left(\tau_{\text {eff }}\right)$ is determined by the chemical passivation effect. As the trends of $\tau_{\text {eff }}, S_{\text {eff }}$, and $I V_{o c}$ at $400{ }^{\circ} \mathrm{C}$ obtained due to ATM annealing have revealed, the chemical passivation effect that affects dangling bonds plays by far a dominant role. 


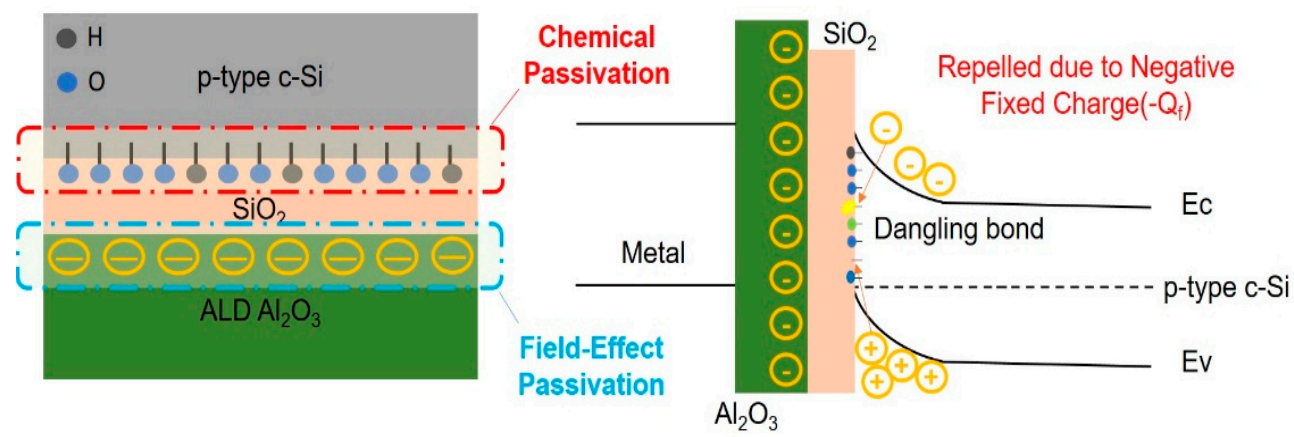

Figure 12. The illustrations of the passivation mechanisms: the chemical passivation and the field-effect passivation of the $\mathrm{Al}_{2} \mathrm{O}_{3} / \mathrm{Si}$ interface.

\subsection{J-V Measurement}

Finally, in this study, a PERC solar cell with a size of $156.75 \mathrm{~mm} \times 156.75 \mathrm{~mm}$ was produced. The current density-voltage (J-V) measurement results of PERC solar cells passivated with $\mathrm{ALD} \mathrm{Al}_{2} \mathrm{O}_{3}$ films of different parameters and the efficiency corresponding to various annealing temperatures are listed in Table 3. All the PERC solar cells have high conversion efficiency between $20.67 \%$ and $21.54 \%$. Among them, the best efficiency value is $21.54 \%$ under $400{ }^{\circ} \mathrm{C}$ in ATM annealing. At $400{ }^{\circ} \mathrm{C}$ annealing temperature, the open-circuit voltage $\left(V_{o c}\right)$ is $673 \mathrm{mV}$, which is very high and rightfully demonstrates that both front and back surfaces are effectively passivated. Due to the effective internal reflectivity at all interfaces between the silicon and the dielectric layer, the highest short-circuit current density $\left(J s c=40.06 \mathrm{~mA} / \mathrm{cm}^{2}\right)$ is achieved under $400{ }^{\circ} \mathrm{C}$ annealing temperature.

Table 3. PERC cell efficiency corresponding to different annealing parameters.

\begin{tabular}{ccccc}
\hline Annealing Temperature & Voc $(\mathbf{m V})$ & Jsc $\left(\mathbf{m A} / \mathbf{c m}^{\mathbf{2}}\right)$ & $\boldsymbol{F F} \mathbf{( \% )}$ & $\boldsymbol{\eta} \mathbf{( \% )}$ \\
\hline $200^{\circ} \mathrm{C}$ & 665 & 39.61 & 79.73 & 20.67 \\
$300^{\circ} \mathrm{C}$ & 667 & 39.73 & 79.08 & 20.87 \\
$400^{\circ} \mathrm{C}$ & 673 & 40.06 & 80.13 & 21.54 \\
$500^{\circ} \mathrm{C}$ & 668 & 39.67 & 79.61 & 20.99 \\
\hline
\end{tabular}

\section{Conclusions}

In this study, $\mathrm{ALD}$ was used to deposit $\mathrm{Al}_{2} \mathrm{O}_{3}$ films on p-type silicon wafers annealed at $200-500{ }^{\circ} \mathrm{C}$ in the atmosphere (ATM), and the $\mathrm{Al}_{2} \mathrm{O}_{3} / \mathrm{Si}$ system was then analyzed. First, the negative fixed charge $\left(Q_{f}\right)$ was measured to find its correlation with the thickness of $\mathrm{SiO}_{2}$. The value of $\mathrm{Q}_{\mathrm{f}}$ rises with the increase of the thickness of $\mathrm{SiO}_{2}$, and reaches the maximum value, or $-4.58 \times 10^{12} \mathrm{~cm}^{-2}$ at an annealing temperature of $500{ }^{\circ} \mathrm{C}$. Second, the defect density $\left(D_{i t}\right)$ of value $7.51 \times 10^{10} \mathrm{~cm}^{-2} \cdot \mathrm{eV}^{-1}$ was extracted at an annealing temperature of $400{ }^{\circ} \mathrm{C}$, which also matches the optimal annealing temperature for the effective minority carrier lifetime. Third, the slowest effective surface recombination velocity (SRV), $S_{\text {eff, }}$ of $4.58 \mathrm{~cm} / \mathrm{s}$ was observed for the $\mathrm{Al}_{2} \mathrm{O}_{3}$ subjected to ATM annealing at $400{ }^{\circ} \mathrm{C}$, unequivocally demonstrating that the dangling bonds situated at the silicon substrate had been properly repaired. Fourth, the longest effective minority carrier lifetime ( $\left.\tau_{\text {eff }}=2181.72 \mu \mathrm{s}\right)$ was recorded which was believably caused by both the chemical passivation effect and the field passivation effect. Finally, a maximum $V_{o c}$ of $727 \mathrm{mV}$ at annealing temperature of $400{ }^{\circ} \mathrm{C}$ was realized. From the perspective of the overall trends of $\tau_{\text {eff }}, S_{\text {eff }}$, and $I V_{o c}$, the chemical passivation effect critically curtails the formation of dangling bonds. In summary, a PERC solar cell size of $156.75 \mathrm{~mm} \times 156.75 \mathrm{~mm}$ was fabricated and VHF PECVD was used to deposit $\mathrm{SiN}_{\mathrm{x}}$ film on the front side as the anti-reflective layer with the very same film on the backside as the cover layer. In conjunction with the use of ATM annealing of $\mathrm{Al}_{2} \mathrm{O}_{3} / \mathrm{Si}$ film at $400{ }^{\circ} \mathrm{C}$, the best cell efficiency value was $21.54 \%$. 
Author Contributions: Conceptualization, Y.-C.H. and R.W.C.; methodology, Y.-C.H.; software, Y.-C.H.; validation, Y.-C.H.; formal analysis, Y.-C.H. and R.W.C.; investigation, Y.-C.H.; resources, Y.-C.H.; data curation, Y.-C.H.; writing-original draft preparation, Y.-C.H.; writing-review and editing, R.W.C. All authors have read and agreed to the published version of the manuscript.

Funding: This research was funded by Bureau of Energy, Ministry of Economic Affairs, R.O.C., Grant No.: 110-D0105.

Institutional Review Board Statement: Not applicable.

Informed Consent Statement: Not applicable.

Data Availability Statement: Data is contained within the article.

Conflicts of Interest: The authors declare no conflict of interest.

\section{References}

1. Hsu, C.H.; Huang, C.W.; Cho, Y.S.; Wu, W.Y.; Wuu, D.S.; Zhang, X.Y.; Zhu, W.Z.; Lien, S.Y.; Ye, C.S. Efficiency improvement of PERC solar cell using an aluminum oxide passivation layer prepared via spatial atomic layer deposition and post annealing. Surf. Coat. Technol. 2019, 358, 968-975. [CrossRef]

2. International Technology Roadmap for Photovoltaic (ITRPV) Results 2017 Incl. Available online: http:/ / www.itrpv.net/Reports/ Downloads / (accessed on 12 June 2021).

3. Nikola, P.; Adam, G.; Rashid, D.; Dinara, S.; Petr, S.; Rastislav, M.; Alois, N.; Lubomír, G. Performance analysis of GaAs based solar cells under gamma irradiation. Appl. Surf. Sci. 2020, 510, 145329. [CrossRef]

4. Kohout, J.; Bousser, E.; Schmitt, T.; Vernhes, R.; Zabeida, O.; Klemberg-Sapieha, J.; Martinu, L. Stable reactive deposition of amorphous $\mathrm{Al}_{2} \mathrm{O}_{3}$ films with low residual stress and enhanced toughness using pulsed dc magnetron sputtering with very low duty cycle. Vacuum 2016, 124, 96-100. [CrossRef]

5. Simoen, E.; Rothschild, A.; Vermang, B.; Poortmans, J.; Mertensa, R. Impact of forming gas annealing and firing on the $\mathrm{Al}_{2} \mathrm{O}_{3} / \mathrm{p}-\mathrm{Si}$ interface state spectrum. ECS Solid State Lett. 2011, 14, H362-H364. [CrossRef]

6. Agostinelli, G.; Delabie, A.; Vitanov, P.; Alexieva, Z.; Dekkers, H.F.W.; De Wolf, S.; Beaucarne, G. Very low surface recombination velocities on p-type silicon wafers passivated with a dielectric with fixed negative charge. Sol. Energy Mater. Sol. Cells 2006, 90, 3438. [CrossRef]

7. Hoex, B.; Schmidt, J.; Bock, R.; Altermatt, P.P.; van de Sanden, M.C.M.; Kessels, W.M.M. Excellent passivation of highly doped p-type $\mathrm{Si}$ surfaces by the negative-chargedielectric $\mathrm{Al}_{2} \mathrm{O}_{3}$. Appl. Phys. Lett. 2007, 91, 112107. [CrossRef]

8. Hoex, B.; Schmidt, J.; Pohl, P.; van de Sanden, M.C.M.; Kessels, W.M.M. Silicon surface passivation by atomic layer deposited $\mathrm{Al}_{2} \mathrm{O}_{3}$. J. Appl. Phys. 2008, 104, 044903. [CrossRef]

9. Dingemans, G.; Engelhart, P.; Seguin, R.; Einsele, F.; Hoex, B.; van de Sanden, M.C.M.; Kessels, W.M.M. Stability of $\mathrm{Al}_{2} \mathrm{O}_{3}$ and $\mathrm{Al}_{2} \mathrm{O}_{3}$ /a-SiNx:H stacks for surface passivation of crystalline silicon. J. Appl. Phys. 2009, 106, 114907. [CrossRef]

10. Sun, W.C.; Chang, W.L.; Chen, C.H.; Du, C.H.; Wang, T.Y.; Wang, T.; Lan, C.W. High efficiency silicon solar cells with bilayer passivation structure. ECS Solid State Lett. 2009, 12, H388. [CrossRef]

11. Dingemans, G.; van de Sanden, M.C.M.; Kessels, W.M.M. Influence of the deposition temperature on the c-Si surface passivation by $\mathrm{Al}_{2} \mathrm{O}_{3}$ films synthesized by ALD and PECVD. ECS Solid State Lett. 2010, 13, H76. [CrossRef]

12. Saint-Cast, P.; Kania, D.; Hofmann, M.; Benick, J.; Rentsch, J.; Preu, R. Very low surface recombination velocity on p-type c-Si by high-rate plasma-deposited aluminum oxide. Appl. Phys. Lett. 2009, 95, 151502. [CrossRef]

13. Saint-Cast, P.; Benick, J.; Kania, D.; Weiss, L.; Hofmann, M.; Rentsch, J.; Preu, R.; Glunz, S.W. High-efficiency c-Si solar cells passivated with ALD and PECVD aluminum oxide. IEEE Electron. Device Lett. 2010, 31, 695. [CrossRef]

14. Rao, R.; Irrera, F. Detrapping dynamics in $\mathrm{Al}_{2} \mathrm{O}_{3}$ metal-oxide-semiconductor. J. Appl. Phys. 2010, 107, 103708. [CrossRef]

15. Miyajima, S.; Irikawa, J.; Yamada, A.; Konagai, M. High quality aluminum oxide passivation layer for crystalline silicon solar cells deposited by parallel-plate plasma-enhanced chemical vapor deposition. Appl. Phys. Express 2010, 3, 012301. [CrossRef]

16. Gielis, J.J.H.; Hoex, B.; van de Sanden, M.C.M.; Kessels, W.M.M. Negative charge and charging dynamics in $\mathrm{Al}_{2} \mathrm{O}_{3}$ films on $\mathrm{Si}$ characterized by second-harmonic generation. J. Appl. Phys. 2008, 104, 073701. [CrossRef]

17. Terlinden, N.M.; Dingemans, G.; van de Sanden, M.C.M.; Kessels, W.M.M. Role of field-effect on c-Si surface passivation by ultrathin (2-20 nm) atomic layer deposited $\mathrm{Al}_{2} \mathrm{O}_{3}$. Appl. Phys. Lett. 2010, 96, 112101. [CrossRef]

18. García-Valenzuela, J.A.; Rivera, R.; Morales-Vilches, A.B.; Gerling, L.G.; Caballero, A.; Asensi, J.M.; Voz, C.; Bertomeu, J.; Andreu, J. Main properties of $\mathrm{Al}_{2} \mathrm{O}_{3}$ thin films deposited by magnetron sputtering of an $\mathrm{Al}_{2} \mathrm{O}_{3}$ ceramic target at different radiofrequency power and argon pressure and their passivation effect on p-type c-Si wafers. Thin Solid Films 2016, 619, 288-296. [CrossRef]

19. Groner, M.D.; Fabreguette, F.H.; Elam, J.W.; George, S.M. Low-temperature $\mathrm{Al}_{2} \mathrm{O}_{3}$ atomic layer deposition. Chem. Mater. 2004, 16, 639-645. [CrossRef]

20. Puurunen, R.L. Surface chemistry of atomic layer deposition: A case study for the trimethylaluminum/water process. J. Appl. Phys. 2005, 97, 121301. [CrossRef] 
21. Dingemans, G.; Kessels, W.M.M. Status and prospects of $\mathrm{Al}_{2} \mathrm{O}_{3}$-based surface passivation schemes for silicon solar cells. J. Vac. Sci. Technol. A 2012, 30, 040802. [CrossRef]

22. Huanga, H.; Lva, J.; Baob, Y.; Xuana, R.; Suna, S.; Sneckc, S.; Lib, S.; Modaneseb, C.; Savinb, H.; Wanga, A.; et al. 20.8\% industrial PERC solar cell: $\mathrm{ALD} \mathrm{Al}_{2} \mathrm{O}_{3}$ rear surface passivation, efficiency loss mechanisms analysis and roadmap to $24 \%$. Sol. Energy Mater. Sol. Cells 2017, 161, 14-30. [CrossRef]

23. Macco, B.; van de Loo, B.W.H.; Kessels, W.M.M. Atomic Layer Deposition for High Efficiency Crystalline Silicon Solar Cells. In Atomic Layer Deposition in Energy Conversion Applications; Bachmann, J., Ed.; Wiley-VCH Verlag: Weinheim, Germany, 2017; pp. 41-99. [CrossRef]

24. Dueñas, S.; Castán, H.; García, H.; de Castro, A.; Bailón, L.; Kukli, K.; Aidla, A.; Aarik, J.; Mändar, H.; Uustare, T.; et al. Influence of single and double deposition temperatures on the interface quality of atomic layer deposited $\mathrm{Al}_{2} \mathrm{O}_{3}$ dielectric thin films on silicon. J. Appl. Phys. 2006, 99, 054902. [CrossRef]

25. Hsu, C.H.; Cho, Y.S.; Wu, W.Y.; Lien, S.Y.; Zhang, X.Y.; Zhu, W.Z.; Zhang, S.; Chen, S.Y. Enhanced Si passivation and PERC solar cell efficiency by atomic layer deposited aluminum oxide with two-step post annealing. Nanoscale Res. Lett. 2019, 14, 139. [CrossRef] [PubMed]

26. Hoex, B.; Heil, S.B.; Langereis, E.; van de Sanden, M.C.; Kessels, W.M. Ultralow surface recombination of c-Si substrates passivated by plasmaassisted atomic layer deposited $\mathrm{Al}_{2} \mathrm{O}_{3}$. Appl. Phys. Lett. 2006, 89, 042112. [CrossRef]

27. Lee, C.Y.; Deng, S.; Zhang, T.; Cui, X.; Khoo, K.T.; Kim, K.; Hoex, B. Evaluating the impact of thermal annealing on c-Si / $\mathrm{Al}_{2} \mathrm{O}_{3}$ interface: Correlating electronic properties to infrared absorption. AIP Adv. 2018, 8, 075204. [CrossRef]

28. Hoex, B.; Gielis, J.J.H.; van de Sanden, M.C.M.; Kessels, W.M.M. On the c-Si surface passivation mechanism by the negativecharge-dielectric $\mathrm{Al}_{2} \mathrm{O}_{3}$. J. Appl. Phys. 2008, 104, 113703. [CrossRef]

29. Takagi, T.; Takechi, K.; Nakagawa, Y.; Watabea, Y.; Nishidab, S. High rate deposition of a-Si:H and a-SiNx:H by VHF PECVD. Vacuum 1998, 51, 751-755. [CrossRef]

30. Bonilla, R.S.; Hoex, B.; Hamer, P.; Wilshaw, P.R. Dielectric surface passivation for silicon solar cells: A review. Phys. Status Solidi A 2017, 214, 1700293. [CrossRef]

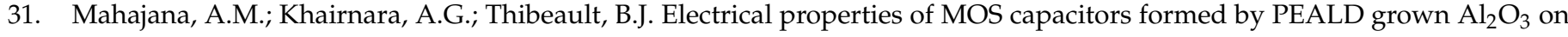
silicon. Semiconductors 2014, 48, 497-500. [CrossRef]

32. Schmidt, J.; Aberle, A.G. Accurate method for the determination of bulk minority-carrier lifetimes of mono- and multicrystalline silicon wafers. J. Appl. Phys. 1997, 81, 6186. [CrossRef]

33. Cuevas, A.; Sinton, R.A. Prediction of the open-circuit voltage of solar cells from the steady-state photoconductance. Prog. Photovolt. 1997, 5, 79-90. [CrossRef] 